\title{
Research on the Development of Self-Built Online Open Courses in
} the New Era

\author{
Xiaofeng $\mathrm{Ma}^{1}$, Qiang $\mathrm{Ji}^{2}$, Yushui Xiao ${ }^{3}$ \\ ${ }^{1}$ Nanyang Institute of Technology, SEGI University, Kuala Lumpur 47810, Malaysia \\ ${ }^{2}$ Henan Polytechnic Institute, Nanyang City 473004, Henan Province, China \\ ${ }^{3}$ SEGI University, Kuala Lumpur 47810, Malaysia
}

\begin{abstract}
Nowadays, online open courses broaden the teaching space, improve the teaching quality, strengthen the learner's autonomous learning ability, and comprehensively promote the innovation of teaching efficiency, quality, content and management system, which brings new opportunities to the education reform. Therefore, self-built online open courses can combine information technology with education, effectively promote the application and sharing of educational resources, and thus comprehensively improve the quality of teaching.

Keywords: New Era; Self-Built Online Open Courses; Information Technology; English

\section{Introduction}

Promoting online open courses is a task that all colleges and universities must to perform. Only by using online teaching platform, can they achieve integration of information technology and educational and teaching resources in depth and realize the application and sharing of resources. The integration of educational resources can be better realized through the improvement of teachers' information ability and teaching ability, and through the promotion of self-built open courses. Innovating teaching mode is the common responsibility of every teacher, which lays a solid foundation for a better educational development prospect ${ }^{[1]}$.
\end{abstract}

\section{Overview of online open courses}

\subsection{Characteristics of online open courses}

Many schools have gradually begun to pay attention to online open courses due to their characteristics. Firstly, online open courses are open access with a broad audience, which includes not only students in school but also social workers who have already worked and can spend their leisure time studying. Secondly, the videos of online open courses are of high quality. Because of the strict requirements of online open courses, each course needs to be carefully produced with the details repeatedly refined, which is a high-quality resource for students. Thirdly, the teaching structure of online open courses can fully meet students' learning needs. Finally, the background data can effectively reflect the learning status of the learners. Teachers can supervise and urge the students to learn, answer their doubts, guide them, etc., based on the specific learning condition of students. That is to say, online open courses is helpful for real-time feedback of the teaching situation ${ }^{[2]}$.

\subsection{Background of online open courses}

Under the background of the new era, China's relevant policy stipulates that in order to effectively promote the reform of teaching, teachers need to master the ability and improve the awareness of applying information technology; it is necessary to strive to speed up the construction of online open courses, and create high-quality online open courses for teaching and sharing. These national policies have pointed out the direction for the construction of online open courses, which at the same time have highlighted the importance the country attaches to online open courses ${ }^{[3]}$.

All colleges and universities have begun to promote the construction of high-quality curriculum resources and the application of information technology, which has instilled energy into previous classroom teaching. Teachers can share the self-built resources and that summarized by the platform to students through the network platform, while students communicate with teachers through the network, thus strengthening the teaching effect and quality. Moreover, teachers participating in self-built courses can integrate teaching resources. That is to say, experience of different teachers in various aspects can enrich teaching resources and comprehensively improve the quality of classroom teaching, thus improving students' learning ability and strengthening their autonomous learning.

Copyright (C) 2020 Xiaofeng Ma et al.

doi: 10.18282/1-e.v9i2.1408

This is an open-access article distributed under the terms of the Creative Commons Attribution Non-Commercial License

(http://creativecommons.org/licenses/by-nc/4.0/), which permits unrestricted non-commercial use, distribution, and reproduction in any medium, provided the original work is properly cited. 


\section{Development requirements for self-built online open courses}

All colleges and universities should construct online open courses following the requirements of the national department. The selection shall be conducted once a year. Under the correct ideological orientation, construction of online open courses should be scientific and reasonable, conform to the selection requirements and indexes in relevant documents, and integrate with ideological and political education. Taking the target audience as the theme of the course, specific design of online open courses can better meet the needs of students, and can also increase students' interest in learning, which better reflects the characteristics of the courses. The construction team should not only pay attention to course plan, but also successfully promote the application and update after the construction, so as to give full play to the advantages of online open courses.

The course construction team should consist of regular members, who treats the work attentively and responsibly. In the construction process of online open courses, there must be clear responsibilities and objectives without mutual prevarication. In order to ensure the quality and effect of the courses, the role of the teaching assistants cannot be ignored, as well as the head of the course construction. The teaching assistants may not participate in the recording of the course video, but they should help the main lecturer with the interaction with students, and take charge in the follow-up update and the collection and replying to students' questions ${ }^{[4]}$.

On the basis of analyzing the current teaching needs, the teaching design with the solution can be worked out and then verified of its effect according to the evaluation and feedback. After improving and revising the teaching design, the purpose of optimizing teaching can be achieved. Setting the beginning and end of teaching based on teaching objects and orderly arranging teaching elements, teaching schemes will be ultimately formed, which can be better applied and practiced in the teaching process.

The basis of curriculum production is the design of script. Before the production of videos for online open courses, the script for teachers' teaching should be prepared, the process of which is the most complicated in the production. The videos are usually 8 to 10 minutes, and the content should be presented accurately in teaching videos. The design of the script is usually completed by the cooperation of the lecturer and the development team. The script should record the content of the lecture in the videos in detail, and note the performance and actions of the lecturer when teaching each knowledge point, which can remind the lecturer during recording videos.

In the process of recording videos, lecturers should give a fluent speech, avoiding irregular language or logical problems. In addition, formal language is necessary. Once there is something to be improved in the video, the recording process can be interrupted and then recorded to facilitate later editing. The lecturer should keep a proper distance from microphone during recording, otherwise it may bring about bad audio-visual experience to students.

After recording, instead of looking away immediately, lecturers should keep their sight on the camera for several seconds. There is various software for video editing, such as iJianJi and PowerDirector. No matter which kind of software is chosen, there should be full preparations.

The content of the online open courses should adhere to the idea of cultivating virtuous people, effectively reflect ideological and political education, reflect the recent research results of the course and the new viewpoint of socialist construction, and reflect the national policies. In addition, students with strong patriotism and a higher scientific level should be cultivated. The advantages of reflecting ideological and political education in the content of the online open courses indicate their own quality and the original construction intention.

Teachers should communicate with students through the self-built course platform and carry out teaching activities including assigning homework, answering doubts and arranging regular examinations according to the requirements of course objectives. The related module should be accessible to students, so teachers can urge students to learn, understand their learning needs and the suggestions on the course platform. Effective communication and collaborative teaching and learning between teachers and students can be achieved through deeply searching the course resources and sharing them on the platform.

\section{Teaching cases based on self-built online open English courses}

\subsection{Preparation stage before English class}

Firstly, teachers assign preparation tasks to students through the online open courses platform. According to the completion of these tasks and their online examination results, teachers can understand students' learning situation in time, and then set the teaching objectives of this English lesson. Secondly, teachers share the resources for students to preview the new lesson and arrange tests on the basis of understanding their learning situation. Students finish the above tasks and exchange opinions on the difficulties and key contents of the learning resources through the discussion module of the platform. Finally, teachers rearrange the curriculum and work out the corresponding teaching design ${ }^{[5]}$.

\subsection{Learning stage in English class}

Students learn new knowledge in English class. Teachers adopt diversified teaching modes and various classroom activities to enable students to learn in a pleasant and relaxed atmosphere. In the classroom teaching, teachers guide students to research collaboratively and further lead them to explore the solutions to the difficult and important problems that students have not solved. According to the feedback of the online open courses, teachers explain the important and difficult contents that they fail to master in the preview stage, and strengthen the weak links in the English learning process. Moreover, the diagnosis of the course learning is the most important link to detect the learning effect of students ${ }^{[6]}$. In order to test the learning effect of students on new knowledge in class, teachers set quizzes on the course platform after the English class. Students finish the quizzes and submit them to the platform, which will be scored automatically by the platform or manually by teachers to give feedback on the students' mastery of new knowledge in real time. Based on the feedback, teachers assign homework accordingly, so that students can learn 
new knowledge from the past and effectively expand English-related knowledge.

\subsection{Consolidation stage after English class}

As mentioned above, teachers should first assign homework according to students' learning condition in English class and share resources with students. The students submit their homework to the course platform. With the automatic review function of the course platform, teachers can upload online explanation videos or leave messages on the platform for repeated mistakes in students' homework and push them to students, so that they can receive feedback of their homework timely. Then students consolidate what they have learned in class by watching the videos shared by teachers ${ }^{[7]}$.

Through the platform of the online open courses, teachers can attach importance to each student's individual development. In addition, the online open courses can achieve the integration of teacher management. Teachers and students summarize and reflect on the teaching and learning process through the communication on the online platform, which effectively makes up the deficiency existing in the previous teaching process and forms interactive and cooperative learning mode.

\section{Conclusion}

This paper introduces the online open courses, analyzes the development requirements of self-built online open courses, and finally gives an example based on self-built online open English courses. Generally speaking, the advent of the Internet era has changed the way to acquire knowledge that learners prefer fragmented learning. Online open courses will surely become the focus of educational research. The integration of offline teaching and online teaching has faced the new development opportunity, which has promoted the reform of traditional teaching mode and also brought new challenges to teachers. Teachers should find a breakthrough in teaching, change the inherent teaching concept, improve teaching methods and improve the efficiency and quality of teaching with the help of online open courses. Meanwhile, under the background of promoting efficient online open courses in the new era, teachers should strengthen their teaching ability and the ability of information design. It is necessary to make the market to work and provide quality services for education informatization through school-enterprise cooperation, thus realizing the promotion of online open courses.

\section{References}

1. Li B, Li B, Zhang Z. Research on the development of self-built online open courses in the new era (in Chinese). Vocational Technology 2020; 19(6): 82-86.

2. Xiong S, Zhu Z. Implementation of ideological and political teaching in mass online open courses. Journal of Ningbo Polytechnic 2019; 23(3): 78-83.

3. Zhou J, Sun C, Tang T, et al. On the construction of online open courses in higher vocational colleges in new era. Journal of Jiujiang Vocational and Technical College 2019; (2): 31-34.

4. Lin L. Analysis on the construction of online courses in application-oriented universities. Journal of Sanming University 2019; 36(1): 89-95.

5. Yu T, Wang T. Application status and improvement strategies of online open courses in local universities under the background of "Internet +" (in Chinese). Computer Knowledge and Technology 2019; 15(5): 127-128+132.

6. Zhang L. National excellent online open courses supporting the construction of massive open online course: Information analysis of national excellent online open courses in 2017 (in Chinese). Survey of Education 2018; 7(21): 122-125+132.

7. Song Y. Construction of service system for online open courses with innovation: Exploration and practice of "icourse" (in Chinese). China University Teaching 2018; (1): 12-16. 